\title{
The changing form of Antarctic biodiversity
}

Steven L. Chown ${ }^{1}$, Andrew Clarke ${ }^{2}$, Ceridwen I. Fraser ${ }^{3}$, S. Craig Cary ${ }^{4}$, Katherine L. Moon $^{1,3} \&$ Melodie A. McGeoch ${ }^{1}$

${ }^{1}$ School of Biological Sciences, Monash University, Victoria 3800, Australia. ${ }^{2}$ British Antarctic Survey, Natural Environment Research Council, High Cross, Madingley Road, Cambridge CB3 0ET, United Kingdom. ${ }^{3}$ Fenner School of Environment and Society, Australian National University, Canberra, ACT 2601, Australia. ${ }^{4}$ International Centre for Terrestrial Antarctic Research, University of Waikato, Private Bag 3105, Hamilton, New Zealand.

Antarctic biodiversity is much more extensive, ecologically diverse and biogeographically structured than previously thought. Understanding of how this diversity is distributed in marine and terrestrial systems, the mechanisms underlying its spatial variation, and the significance of the microbiota is growing rapidly. Broadly recognizable drivers of diversity variation include energy availability and historical refugia. The impacts of local human activities and global environmental change nonetheless pose challenges to current and future understanding of Antarctic biodiversity. Life in the Antarctic and the Southern Ocean is surprisingly rich, and as much at risk from environmental change as it is elsewhere.

The past two decades have witnessed a revolution in the approaches used to document patterns in and the functional significance of the diversity of life. Knowledge of the global distributions of organisms now extends to many groups. These include terrestrial plants and animals ${ }^{1}$, marine taxa ${ }^{2}$, components of the soil biota ${ }^{3}$, and, increasingly, microorganisms ${ }^{4}$. 
Empirical and theoretical research is verifying the range of mechanisms, including energy and nutrient availability, and historical contingency, that are responsible for these patterns ${ }^{1,2}$, and the role of diversity in maintaining ecosystem services. New approaches are also revealing rapid changes in diversity across most ecosystems, their often negative implications for the future of the planet, and our struggle to address the problem ${ }^{5}$.

In tandem, biodiversity research has surged across the Antarctic and Southern Ocean. In part the increasing interest has been driven by the realization that any fundamental quest to understand life's diversity requires exploration of the polar regions ${ }^{6,7}$. But it has also been underpinned by a growing appreciation of the particular challenges faced by Antarctic species and ecosystems. Climate change ${ }^{8}$, and economic activity in the form of fishing, tourism, and scientific research itself ${ }^{9,10}$ are all having impacts on Antarctic diversity. The intricacy of Southern Ocean food webs, best known for the region's iconic seals, penguins, whales and albatrosses, has been further unveiled, so highlighting the complexity of the simultaneous impacts of changing climates, sea ice distribution and fisheries on this system ${ }^{11,12}$. New marine research has also exposed unexpectedly high benthic diversity, including in the deep sea $^{13,14}$. In terrestrial areas, the diversity of higher plants and animals is relatively low (e.g., just two flowering plant species), but the diversity of lichens, bryophytes, invertebrates, and the microbiota is substantial ${ }^{15}$. Local and regional spatial patterning in these groups is extensive ${ }^{16}$, with the mechanisms underlying these patterns both recognizable from broader ecological theory and unusual in several respects.

Here we explore recent advances in our understanding of the biodiversity of the Antarctic. Given the many conservation challenges it faces, we also consider how well the region is performing in relation to an aspirational set of global conservation benchmarks, the Aichi Targets ${ }^{5}$. Biodiversity conventionally encompasses variability across the entire biological hierarchy, from genes to ecosystems and their functioning. In the Antarctic, 
significant recent progress has been made on all of these fronts ${ }^{17}$. In this review we focus primarily on ecological diversity, its drivers, and changes that are being wrought by both local anthropogenic and global environmental change. We first bring together recent studies that have advanced our understanding of the diversity of marine and terrestrial groups, including the microbiota, and their evolution in the region. We then show how ecological and historical processes shape diversity and how they might change into the future. Finally, we assess Antarctic conservation in a global context, and highlight the biodiversity research challenges facing the region. Doing so is especially timely given the escalating political prominence of the Antarctic, owing to debates about use of its resources, and the growing extent of science, fishing and tourism and their likely impacts.

\section{Marine richness, species flocks and diversification}

The traditional view of Antarctic marine metazoan diversity has been of a species-poor fauna constrained by a harsh environment. Some groups are genuinely depauperate in the Southern Ocean, notably teleost fish, gastropods, bivalves and some crustaceans. Initial work on these groups largely shaped early views of the fauna as a whole. By the turn of the century, however, benthic diversity was thought to be high with much of the fauna remaining undiscovered or undescribed $^{18}$. Substantial sampling and systematic campaigns associated with the Census of Marine Life have since supported this idea ${ }^{19}$. More than 8,000 valid

marine species are now known for the Southern Ocean, most of which are benthic ${ }^{14}$. Many of the new taxa have come from sampling of the deep Southern Ocean. For example, campaigns in the deep Weddell Sea recovered 674 isopod species, of which more than $80 \%$ were new to science $^{13}$. The Southern Ocean is clearly not the universally depauperate region it was originally thought to be. Benthic sampling has also improved understanding of the evolution of unusual groups such as the acorn worms. Individuals collected along the West Antarctic 
Peninsula and in the Ross Sea live in secreted translucent tubes, making them similar to acorn worms of the Middle Cambrian, demonstrating conservation of this behaviour for 500 million years $^{20}$.

Recent work has consolidated the view that strong latitudinal marine diversity gradients, with declines in species richness to the poles, are more general for the northern than southern hemisphere ${ }^{21}$. Indeed, for groups such as hexacorals (excluding scleractinians), pycnogonids and bryozoans, current knowledge suggests that diversity in the Southern Ocean is comparable with many temperate and non-reef tropical habitats ${ }^{14}$. In others, such as the petrels, albatrosses and their relatives, diversity patterns are atypical, with diversity peaks not in the tropics, nor at the highest southern latitudes, but rather in the productive areas between $35^{\circ} \mathrm{S}$ and $50^{\circ} \mathrm{S}^{22}$. The distinctiveness of the Southern Ocean fauna is also much higher than previously thought. Recent estimates suggest that 50 to $97 \%$ of Southern Ocean species in various groups such as sponges, tube worms, amphipods, molluscs, isopods, sea spiders and notothenioid fish are endemic ${ }^{14}$. The deep sea fauna is also quite different to that of other regions ${ }^{13}$. For example, the hydrothermal vent faunas of the East Scotia Sea lack the polychaete worms, alvinocaridid shrimp, and bathymodiolid mussels typical of other vent systems; instead these vents are characterized by peltospiroid gastropods, stalked barnacles, sea stars, and a previously unknown anomuran yeti crab species ${ }^{23}$. These differences suggest that the insights into metabolic functioning and the evolution of symbioses that have come from the exploration of deep-sea hydrothermal vents elsewhere ${ }^{24}$ may be significantly extended through examination of Antarctic vent faunas.

Investigation of the high marine endemicity has revealed how a complex set of earth system processes, including glaciation, differential diversification, and isolation, has interacted to shape the evolution of the southern biota ${ }^{25}$. In turn, the outcomes of this evolutionary interaction, such as the uniquely high prevalence in the region of marine 
invertebrate species lacking a planktonic larval phase ${ }^{26}$, have profound consequences for responses to ongoing global environmental change, and for forecasting them, owing to variation in dispersal capability.

One factor contributing to the rapid rise in estimates of diversity of the Southern Ocean has been the identification, typically using molecular approaches, of many cryptic species $^{19}$. For example, within each of four Orchomenella amphipod species, several wellsupported clades have been found that probably represent reproductively-isolated species ${ }^{27}$. Evidence of cryptic speciation is also present in Antarctic isopods ${ }^{28}$, echinoderms ${ }^{29}$, and sea slugs. In the latter, an original single species, Doris kerguelenensis, is now thought to comprise a species flock, with diversification driven by predation ${ }^{30}$. Several other invertebrate groups, including echinoids, isopods and amphipods, may also qualify as marine species flocks ${ }^{31}$. Notothenioid fishes have long been recognized as a species flock, particularly those with antifreeze glycoproteins ${ }^{31}$, and the broad group includes several subclade radiations that have been linked to periods of climate change ${ }^{32}$ (Fig. 1). Exploration of the way in which these species flocks have developed has provided much insight into evolutionary processes associated with rapid diversification, and those associated with survival in Antarctic waters ${ }^{33}$.

The cyclical waxing and waning of the ice sheets has been a major driver of range fragmentation and allopatric speciation in several marine benthic groups. Although much of the shelf and slope will have been inimical to life at glacial maxima ${ }^{34}$, and some shelf taxa undoubtedly retreated to the deep sea, palaeobiological and biogeographic evidence, coupled with recent molecular research, indicates that many species have persisted on the shelf throughout numerous glacial cycles ${ }^{35}$. These taxa could have survived glacial periods in situ in regions where the ice sheet did not extend to the edge of the continental shelf ${ }^{36}$, particularly where polynyas were formed by katabatic winds at shelf margins. Changes in sea 
level, together with partial collapses of the West Antarctic Ice Sheet between 1.1 Ma and 125 ka BP, may have allowed faunal exchange through seaways across the Antarctic continent, now closed by ice ${ }^{37}$ (Fig. 1). These events have resulted in substantial biogeographic structuring $^{38}$. The Southern Ocean is therefore not a relatively uniform region, but is biogeographically complex, with considerably more local structuring than previously thought. Few taxa appear to be truly circumpolar, and in species initially believed to have broad (or even circumpolar) distributions subsequent phylogeographic work is revealing multiple species/divergent lineages with more restricted ranges ${ }^{27,29}$.

\section{Diversity in the terrestrial biota}

Although flowering plant diversity is low in the Antarctic, other groups, such as the lichens $\left(>200\right.$ species) and mosses (> 100 spp.), are comparatively species-rich ${ }^{39}$. Some terrestrial invertebrate groups are also well represented, including the tardigrades, nematodes, springtails and mites ${ }^{40,41}$. The distribution patterns of these organisms are highly variable. Recent phylogeographic work shows that while some species appear truly circum-Antarctic in their distribution (e.g. rotifers and nematodes ${ }^{41,42}$ ), others, such as springtails, are much more differentiated ${ }^{43}$. By coupling the growing availability of continent-wide biodiversity databases with ecoinformatic approaches, recent analyses have shown substantial spatial patterning in diversity across the continent, with fifteen distinct ecoregions now recognized on the continent itself, and another eight across the Southern Ocean islands ${ }^{44}$. Much diversity within species, at local spatial scales of hundreds of metres to hundreds of kilometres, is also being discovered through phylogeographic approaches, reflecting the effects of both older glacial history and more recent events ${ }^{7}$.

As with marine groups, substantial cryptic diversity has been unveiled in the terrestrial metazoan biota $^{42,45}$ and its diversity is likely much higher than is currently 
appreciated. Moreover, for most groups, including those that are considered well known, the full extent and structure of the continent's diversity remains partially understood because much of it has not been thoroughly surveyed ${ }^{46}$. Although the overall area of ice free land is small, about $46,000 \mathrm{~km}^{2}$ (about $1 / 3$ the area of England) or less than $0.5 \%$ of the continent's surface area, a great deal of it is remote and difficult to access.

The bulk of Antarctica's terrestrial diversity lies in the less visible groups, represented by the microbiota. Metagenomics has substantially improved current understanding of both its structure and functioning ${ }^{6,47,48}$. Early, culture-dependent studies provided only a superficial glimpse of the resident terrestrial microbial diversity. Independent, comparative studies from around the continent, using next-generation sequencing technologies and metagenomic approaches, concur that terrestrial microbial community phylogenetic and taxonomic diversity are typically higher than once thought. Nonetheless, this diversity is lower than in many temperate soil systems, probably the result of selection imposed by the generally cold, dry, oligotrophic nature of the Antarctic soil system ${ }^{49,50,51}$, though in some areas soils are moist and enriched by the activities of seabirds and seals.

At the phylum level, Antarctic soils appear to be structured similarly to soils elsewhere, dominated by the Acidobacteria, Proteobacteria, Actinobacteria and Bacteroidetes. However, when examining individual "species" composition, the picture is very different, suggesting selection for a highly adapted and specialized community ${ }^{52}$. Metagenomic approaches have revealed much higher community-level genetic plasticity than originally suggested for these extreme oligotrophic mineral soils, especially in autotrophic, heterotrophic, and diazotrophic lifestyles along with significant representation of thermal, osmotic, dormancy and nutrient limitation stress response pathways ${ }^{51,53}$. These metagenomic surveys are beginning to provide clues as to what might drive community assembly and interactions and ultimately their success. They have also identified the presence of antibiotic 
resistance genes and a prominence of phage signals ${ }^{48}$, suggesting that some level of cell competition and interaction may exist that could also play a critical role in structuring these communities where the role of grazers remains uncertain.

Terrestrial Antarctica also harbours a remarkable diversity of aquatic systems ranging from thousands of small ponds and lakes scattered across the terrestrial and ice shelf landscape to the recently accessed, extensive network of subglacial lakes and streams. The lakes and ponds range from permanently ice covered to perennially ice free, freshwater to hypersaline, and highly stratified to permanently mixed, with much variation in geochemistry ${ }^{6}$. These features are all microbially dominated and, like Antarctic soils, generally support relatively low diversity communities when compared to similar temperate systems $^{54}$. Metagenomic surveys suggest that this might not be the case for viruses, with Antarctic lakes supporting the highest diversities of viruses in any aquatic system yet examined $^{15}$, emphasizing their functional and evolutionary significance ${ }^{55}$. Microbial mats, especially important systems in polar aquatic environments, also harbour high diversity, with members that include cosmopolitan and apparently endemic elements, both in mats on land and those on ice shelves ${ }^{56}$. Perhaps most significantly from an evolutionary perspective, the retrieval of samples from subglacial Lake Whillans has validated the assertion that life exists below the Antarctic ice sheets ${ }^{57}$. The lake supports a diverse, metabolically active, chemosynthetic community of Bacteria and Archaea, possibly relying on the oxidation of ammonia originating from microbial mineralization in the sediments laid down some 120,000 years ago.

\section{Drivers of diversity}

Globally, the drivers of diversity have become increasingly well characterized, although controversy about their relative significance continues. Historical events such as glaciations 
and continental drift, along with dispersal have played major roles. Energy availability, in the form of primary productivity, is likewise important for determining variation in species richness ${ }^{1}$. Other factors influencing diversity include temperature, surface area, spatial and temporal heterogeneity in conditions, and interactions among organisms such as through predation and disease. Spatial scale and location play major roles in determining which of these factors are most significant. For Antarctic marine and terrestrial systems the same sets of drivers are often important.

In marine systems, richness varies with available energy, disturbance, and local heterogeneity, while climate cycles and long-term oceanic conditions have influenced which groups are diverse and which are less well-represented ${ }^{7}$. Nonetheless, some of the drivers of diversity in the Antarctic are unusual, providing unique insights into the ongoing controversy. For example, spatial variation in the global richness of albatrosses, petrels and their relatives, which peak in diversity in the region, is positively related to the availability of large, contiguous areas of ocean, temperature and wind speed, all of which nonetheless represent forms of available energy ${ }^{22}$. Wind energy is especially interesting because it is rarely considered during investigations of the drivers of species richness, but can clearly be important, as studies of individual species of seabirds have demonstrated ${ }^{58}$. Moreover, winds are strengthening substantially in the region as a consequence of a southward shift and increase in intensity of the westerlies, partly as a result of anthropogenic ozone depletion ${ }^{8}$. For species which rely on wind energy these changes should prove beneficial. Recent analyses of long-term life history and population data on wandering albatrosses support such an effect ${ }^{59}$. For breeding adults on the Crozet Islands (located at $46^{\circ} \mathrm{S}$ in the Southern Indian Ocean), rates of travel and flight speeds have increased and the duration of foraging trips has decreased over the past 20 years. Breeding success has consequently improved. Breeding 
birds have also gained about $1 \mathrm{~kg}$ in mass (individual birds weigh about 8-11 kg), which may represent an adaptive response to windier conditions.

In terrestrial Antarctic systems, as is the case for those elsewhere, the availability of energy and water are the two most important drivers of metazoan diversity. Across broader scales, moss, lichen and liverwort species richness is positively related to temperature ${ }^{16,60}$, though south of $72^{\circ} \mathrm{S}$ a suite of local microclimate factors including temperature, available water, light and shelter may be more important than energy alone. These gradients emphasize the importance of temperature in dictating the availability of water, though at local scales individual species distributions are typically also influenced by soil parameters, such as Carbon and Nitrogen availability ${ }^{7,42}$. Where geothermal energy warms the ground, the availability of resources is higher both spatially and seasonally. Such consistent energy availability has played a major historical role in determining patterns of diversity across the continent. Analyses of a large database on the distribution of diversity in the region have revealed that for plants and fungi (mostly lichens) the presence of geothermal sites, such as volcanoes, explains much of the variation in diversity. This pattern extends beyond the immediate vicinity of these areas, suggesting that such sites have served as refugia for long periods, including during the Pleistocene glaciations ${ }^{61}$. Refugia such as these, as well as inland nunataks and coastal areas, have likely all played major roles in determining the distribution of many of the continent's terrestrial organisms ${ }^{62}$. The extent to which the importance of these drivers varies among different groups remains unknown, however, because of limited biodiversity surveys. Nonetheless, the importance of energy availability and refugia in terrestrial systems mean that the drivers of diversity for metazoans here have many parallels with those of the Antarctic marine environment.

Although most macrofauna and even some micro-eukaryotes show strong continental regionalization, much local structural heterogeneity in soil microbial communities has been 
revealed by regional and landscape-scale studies. Prokaryotic diversity variation, especially south of $70^{\circ} \mathrm{S}$, may thus be driven predominantly by local microclimate and landscape history ${ }^{63,64}$. Soil surface ages and frequency of water availability establish severe gradients in $\mathrm{pH}$, soil moisture and salinity that appear to be primary drivers for microbial community selection. Certain dominant components of the edaphic community, such as cyanobacteria, may be structured both by niche-related factors, such as in the case of communities living below and within rocks ${ }^{64}$, and in other circumstances by dispersal-related spatial filters (i.e. wind processes) at a local scale. Recent studies examining the presence, composition, and local contributions of a possible continental-wide aeolian microbial community suggest that this community is primarily of Antarctic origin with some contribution of more resilient taxa from off-continent sources ${ }^{65}$. The Antarctic aerosolized community appears to have little impact on the less optimal cold dry edaphic mineral soil communities, but makes a substantial contribution to the significantly more selective geothermal soils ${ }^{66}$.

For most lakes and ponds, geochemistry appears the primary driver for microbial community composition and structure, in keeping with the situation for many water bodies globally. Although mixing between nearby and disparate ponds and lakes probably occurs $^{67,68}$, those with similar geochemistry (i.e. conductivity and/or nutrients) support similar communities, at least at the higher taxonomic level, regardless of location ${ }^{69,70}$. This appears especially true for the more isolated bottom water of permanently stratified lakes as evidenced by the high level of sequence divergence seen in certain groups ${ }^{71}$. Even some of the micro-eukaryotes appear to have very specific geochemically driven requirements, while others are considerably more cosmopolitan ${ }^{72}$.

\section{Diminishing isolation}


An enduring concept is that the Antarctic biota has been isolated since the breakup of Gondwana. Geologically, the terrestrial link between Antarctica and South America was severed in the Eocene, and deep-water flow of the Antarctic Circumpolar Current (ACC) was initiated in the late Oligocene ${ }^{73}$. With the onset of the ACC came circumpolar thermal fronts such as the Subtropical Front (STF) and Antarctic Polar Front (APF) (Fig. 1), which define the boundary zones between Antarctic, sub-Antarctic and temperate waters. Steep temperature gradients and limited water exchange across these zones created dispersal barriers, exacerbated by strong, circumpolar winds and currents that promote eastward dispersal, but hinder north-south movement ${ }^{74,75}$. Although the APF has been a formidable challenge to faunal exchange, it is not an absolute barrier ${ }^{76,77}$. Phylogeographic research now supports the idea of dispersal across the APF in a range of marine groups, such as molluscs $^{78,79}$, echinoderms ${ }^{80,81}$, and crustaceans ${ }^{74}$. Many successful colonisations appear to have preceded Pliocene intensification of the $\mathrm{ACC}^{77}$, but occasional dispersal events into and out of Antarctic waters have occurred since that epoch ${ }^{75,82}$. Similar dispersal events across the APF, over the same timescales, have occurred in terrestrial bryophytes and invertebrates ${ }^{45,46}$. For important elements of the terrestrial microfauna, such as the tardigrades, rotifers and nematodes, information remains too sparse to reach general conclusions ${ }^{41}$, though long-term isolation in the continental Antarctic seems to be the case for some groups such as the mites and springtails ${ }^{62}$.

The rarity of natural dispersal events has, until recently, allowed Antarctica's biota to evolve and diversify in relative isolation ${ }^{83}$. Signals of natural dispersal, colonisation and diversification for Antarctica are now at risk of being overwhelmed by impacts associated with changing climates and rapidly increasing human movement both into the region and between its distinct ecoregions. For example, $20 \%$ of tourist and $45 \%$ of scientific visitors to Antarctica carry plant propagules from species growing elsewhere, with more than 70,000 
seeds estimated to be entering the region annually ${ }^{84}$. Many of these are from regions such as the Arctic and sub-Antarctic, where conditions are similar to more benign parts of the continent, making establishment in Antarctica more likely. Some of these species have already established at several locations, such as annual bluegrass, Poa annua, which is a superior competitor to the only two indigenous vascular plant species found along the Antarctic Peninsula ${ }^{85}$. Newly arrived terrestrial species continue to be documented ${ }^{86}$, and climate change is expected to increase the likelihood of establishment and further impact by non-indigenous species.

Some parts of the Antarctic marine system may be similarly affected, especially shelf environments. Ship traffic to the Antarctic carries a diverse assemblage of non-indigenous species as fouling ${ }^{87}$, and such traffic is heavy to the Antarctic Peninsula. Here, one widelydiscussed risk is the spread of crabs with the potential for substantial changes to the benthic system $^{88}$ (Box 1). What the risks are for invasion of other areas of the Antarctic by marine groups is not clear, with understanding for the broader region poorly developed compared with terrestrial systems, stimulating controversy about the likely significance of marine invasions $^{89}$.

\section{Antarctica and the strategic plan for biodiversity}

Knowledge of the negative consequences of global change for the increasingly apparent scope and novelty of Antarctic biodiversity is growing (Box 1). A useful perspective on how well conservation of the region is performing by global standards comes from the Convention on Biological Diversity's (CBD) Aichi Targets of the Strategic Plan for Biodiversity 2011$2020^{5}$.

The Antarctic region is largely an international space governed predominantly through the Antarctic Treaty System (which applies to all areas south of $60^{\circ} \mathrm{S}$ ), to which 52 
countries are party. Environmental matters are the main concern of its Committee for Environmental Protection (CEP) and the Convention on the Conservation of Antarctic Marine Living Resources (CCAMLR) ${ }^{90}$. In consequence, the region is typically not subject to many global agreements such as the CBD. Nonetheless, many of the Antarctic Treaty Parties are also signatory to these international agreements, including the $\mathrm{CBD}$, and are actively developing plans to achieve the Aichi Targets ${ }^{91}$.

The Aichi Targets encompass 20 aspirational goals for global biodiversity conservation. Not all of them are immediately relevant to the Antarctic. For example, Targets 7, 13 and 18 are not germane because the activities and species they cover, and indigenous human populations, are typically absent from the region. Many of the targets could, however, be applied to the Antarctic (Box 2). Of these, only performance against Target 11, concerning protected areas, has been explicitly assessed ${ }^{92}$. Just $1.5 \%$ of the continent's ice-free area is formally designated as specifically protected, and five of its 15 ecoregions have no protection. Antarctic terrestrial biodiversity protection thus falls short of the $17 \%$ area coverage proposed in Target 11, and by some accounts management is insufficiently effective too $^{93}$. Similar assessments have not been made for marine protected areas (MPAs), but only one exists in the Treaty Area. Together with recent controversy about the inability of the parties to CCAMLR to agree on Antarctic MPAs, this situation suggests that for marine systems, area protection is poorer than for the terrestrial Antarctic.

For the remainder of the relevant Aichi targets, the available evidence suggests that were assessments to be made, the region might fare poorly in all except perhaps Targets 8 and 9 (Box 2). The reduction of pollution to levels that are not detrimental to ecosystem function and biodiversity is the subject of Target 8 . Much progress has been made in addressing pollution, though in some areas significant problems still exist ${ }^{94}$. Target 9 specifies that by 2020, invasive alien species and pathways of introduction should be 
identified and prioritized, priority species controlled or eradicated, and measures put in place to prevent the introduction and establishment of such species. The Antarctic Treaty Parties have taken significant, evidence-based steps to identify pathways of invasion and priority species, and to prevent introduction and establishment, based on the advice of the CEP ${ }^{95}$.

\section{Outlook and challenges}

The importance of science in and about the Antarctic region has recently been re-emphasized by the identification of 80 key questions that are on the scientific horizon for the region ${ }^{17}$. Many of these questions illustrate the major role science will play in mitigating the consequences of environmental impacts in the Antarctic and in providing the information required for evidence-based policy to do so both locally and globally. Perhaps more importantly from a fundamental science perspective, they also recognize that human activities in the Antarctic and elsewhere may be compromising current approaches and future ability to understand biodiversity and ecosystem functioning in the region.

From this perspective and from what is now known about biodiversity in the region, several challenges remain. First among these is inadequate knowledge of terrestrial diversity in many areas, for many taxa, and the absence of any coordinated program to rectify the situation. In the face of substantial activity across the region, and the clear indication of regional diversification in many groups, signals of phylogenetic and functional distinctiveness, especially in the microbiota, may be compromised substantially. Risks of introduction of non-indigenous taxa are not only from outside the continent, but also from regions that are significantly differentiated on the continent, at both continent-wide and local scales $^{93}$. Comprehensive understanding of how diversity patterns and the mechanisms underlying them vary among major groups, and among major areas (such as above and below about $70^{\circ} \mathrm{S}$ ), is yet to be developed, restricting comparisons with elsewhere and with marine 
systems. Biotic homogenization as a consequence of both scientific and non-scientific activities would certainly obscure understanding, though to what extent this might happen is itself unknown.

The importance of limiting local impacts from human activities has been further emphasized by recent work showing that responses to climate change, and in particular to pulse events, may be rapid ${ }^{96}$. Increases in water availability and carbon as a result of warmer wetter summers, and progressively warming regional climates as seen in the Peninsula ${ }^{8}$, could radically alter biodiversity in the continent's ice-free areas on a near-immediate time scale, such as by increasing growth rates and activity periods, so increasing abundance and richness. Understanding the likelihood of such change and documenting it presupposes a limited influence of local disturbance.

A similar situation is true of marine systems (Box 1), where understanding of the functioning and dynamics of large, relatively undisturbed ecosystems remains a significant goal of ecology. Until recently, this goal may well have been possible for the Antarctic given low impacts on the Ross Sea system, acknowledging the roles played by whales and seals that were removed in large numbers in the $19^{\text {th }}$ and $20^{\text {th }}$ centuries ${ }^{97}$. Now, that possibility is under threat. Changes in stratospheric ozone and greenhouse gases are driving substantial alterations to sea ice concentrations and seasonality, and ocean $\mathrm{pH}$ in the system ${ }^{97}$, and little progress has been made in securing the area from the local, and significant, impacts of fishing ${ }^{98}$. Establishing a substantial Marine Protected Area for the Ross Sea is not only significant for conservation, but also for the scientific value of retaining a large marine system that is not being simultaneously affected by both global anthropogenic drivers and local ones. Few such other marine systems exist. More generally, the situation reflects the absence of substantial national collaboration to achieve region-wide conservation objectives. No commitment to anything equivalent to the Aichi Targets exists for the region, and the 
Antarctic Treaty System remains underfunded, with new activities typically not reaching consensus because of budgetary concerns. In the face of growing challenges presented by fishing and interest in the Antarctic's other resources ${ }^{99,100}$, the situation is especially concerning.

Rapid developments in a range of areas nonetheless suggest that, from a science perspective, many of the challenges can be overcome. These include new DNA archival approaches that enable samples collected from rare visits to remote sites to be stored and reinvestigated repeatedly ${ }^{101}$, satellite remote sensing that enables total population counts ${ }^{102}$ and identification of areas with significant metazoan diversity ${ }^{103}$, and new analytical tools to enable comparisons among multiple groups and regions ${ }^{104}$. Approaches that limit the influence of scientific activities on the very systems being investigated are also developing rapidly $^{57}$. The application of these developments will mean a larger transformation in understanding of Antarctic biodiversity over the next 20 years than its change over the last century. In so doing investigations of a globally unusual and important system will continue to contribute to general understanding of the planet's diversity and ecosystems, and at the same time provide further evidence to support its stringent conservation.

1. Gaston, K. J. Global patterns in biodiversity. Nature 405, 220-227 (2000).

2. Belanger, C. L. et al. Global environmental predictors of benthic marine biogeographic structure. Proc. Natl. Acad. Sci. U.S.A. 109, 14046-14051 (2012).

3. Tedersoo, L. et al. Global diversity and geography of soil fungi. Science 346, 1256688 (2014).

4. Barberán, A., Casamayor, E. O. \& Fierer, N. The microbial contribution to macroecology. Frontiers Microbiol. 5, 203 (2014). 
5. Tittensor, D. P. et al. A mid-term analysis of progress toward international biodiversity targets. Science 346, 241-244 (2014).

6. Wilkins, D. et al. Key microbial drivers in Antarctic aquatic environments. FEMS Microbiol. Rev. 37, 303-335 (2013).

7. Convey, P. et al. The spatial structure of Antarctic biodiversity. Ecol. Monogr. 84, 203244 (2014).

8. Turner, J. et al. Antarctic climate change and the environment: an update. Polar Rec. 50, 237-259 (2014).

9. Tin, T. et al. Impacts of local human activities on the Antarctic environment. Antarct. Sci. 21, 3-33 (2009).

10. Ainley, D. G. \& Pauly, D. Fishing down the food web of the Antarctic continental shelf and slope. Polar Rec. 50, 92-107 (2014).

11. Constable, A. J. et al. Climate change and Southern Ocean ecosystems I: how changes in physical habitats directly affect marine biota. Global Change Biol. 20, 3004-3025 (2014).

12. Saba, G. K. et al. Winter and spring controls on the summer food web of the coastal West Antarctic Peninsula. Nature Comms. 5, 4318 (2014).

13. Brandt, A. et al. First insights into the biodiversity and biogeography of the Southern Ocean deep sea. Nature 447, 307-311 (2007).

This study of benthic diversity challenged the notion that deep-sea diversity is depressed in the Southern Ocean, with its findings borne out by recent comprehensive surveys.

14. De Broyer, C. et al. Biogeographic Atlas of the Southern Ocean. (Scientific Committee on Antarctic Research, Cambridge, 2014). 
15. López-Bueno, A. et al. High diversity of the viral community from an Antarctic lake. Science 326, 858-861 (2009).

This study showed that an Antarctic lake viral community has high genetic richness distributed across the highest number of viral families found in aquatic viral genomes, with a substantial proportion of sequences related to eukaryotic viruses, unlike the situation for other aquatic viromes.

16. Casanovas, P., Lynch, H. J. \& Fagan, W. F. Multi-scale patterns of moss and lichen richness on the Antarctic Peninsula. Ecography 36, 209-219 (2013).

17. Kennicutt, M. C., II et al. Six priorities for Antarctic science. Nature 512, 23-25 (2014).

18. Janosik, A. M. \& Halanych, K. M. Unrecognized Antarctic biodiversity: a case study of the genus Odontaster (Odontasteridae; Asteroidea). Integr. Comp. Biol. 50, 981-992 (2010).

19. Kaiser, S. et al. Patterns, processes and vulnerability of Southern Ocean benthos: a decadal leap in knowledge and understanding. Mar. Biol. 160, 2295-2317 (2013).

20. Halanych, K. M., Cannon, J. T., Mahon, A. R., Swalla, B. J. \& Smith, C. R. Modern Antarctic acorn worms form tubes. Nature Comms. 4, 2738 (2013).

21. Clarke, A. in Marine Macroecology (eds Witman, J. D. \& Roy, K.) 250-278 (University of Chicago Press, Chicago, 2009).

22. Davies, R. G., Irlich, U. M., Chown, S. L. \& Gaston, K. J. Ambient, productive and wind energy, and ocean extent predict global species richness of procellariiform seabirds. Global Ecol. Biogeogr. 19, 98-110 (2010).

23. Rogers, A. D. et al. The discovery of new deep-sea hydrothermal vent communities in the Southern Ocean and implications for biogeography. PLoS Biol. 10, e1001234 (2012). 
This study showed that the fauna of deep-sea hydrothermal vents on the East Scotia Ridge in the Southern Ocean is wholly different to vent faunas elsewhere, demonstrating that Antarctic endemicity extends to these faunas.

24. Petersen, J. M. et al. Hydrogen is an energy source for hydrothermal vent symbioses. Nature 476, 176-180 (2011).

25. Crame, J. A. Early Cenozoic differentiation of polar marine faunas. PLoS One 8, e54139 (2013)

26. Marshall, D. J., Krug, P. J., Kupriyanova, E. K., Byrne, M. \& Emlet, R. B. The biogeography of marine invertebrate life histories. Annu. Rev. Ecol. Evol. Syst. 43, 97114 (2012).

27. Havermans, C., Nagy, Z. T., Sonet, G., De Broyer, C. \& Martin, P. DNA barcoding reveals new insights into the diversity of Antarctic species of Orchomene sensu lato (Crustacea: Amphipoda: Lysianassoidea). Deep Sea Res. II 58, 230-241 (2011).

28. Raupach, M. J., Malyutina, M., Brandt, A. \& Wägele, J.-W. Molecular data reveal a highly diverse species flock within the munnopsoid deep-sea isopod Betamorpha fusiformis (Barnard, 1920) (Crustacea: Isopoda: Asellota) in the Southern Ocean. Deep Sea Res. II 54, 1820-1830 (2007).

29. Wilson, N. G., Hunter, R. L., Lockhart, S. J. \& Halanych, K. M. Multiple lineages and absence of panmixia in the "circumpolar" crinoid Promachocrinus kerguelensis from the Atlantic sector of Antarctica. Mar. Biol. 152, 895-904 (2007).

This broad-scale study challenges the generalization that many Antarctic species have circumpolar distributions, instead suggesting that much unrecognized diversity and geographic structure exists in the Antarctic biota. 
30. Wilson, N. G., Maschek, J. A. \& Baker, B. J. A species flock driven by predation? Secondary metabolites support diversification of slugs in Antarctica. PLoS One 8, e80277 (2013)

31. Lecointre, G. et al. Is the species flock concept operational? The Antarctic shelf case. PLoS One 8, e68787 (2013).

32. Near, T. J. et al. Ancient climate change, antifreeze, and the evolutionary diversification of Antarctic fishes. Proc. Natl. Acad. Sci. U.S.A. 109, 3434-3439 (2012). This study showed that although antifreeze was acquired early in the evolution of notothenioid fishes in Antarctica, the main burst of diversification was much more recent, probably during the Late Miocene cooling.

33. Cziko, P. A., DeVries, A. L., Evans, C. W. \& Cheng, C. H. C. Antifreeze proteininduced superheating of ice inside Antarctic notothenioid fishes inhibits melting during summer warming. Proc. Natl. Acad. Sci. U.S.A. 111, 14583-14588 (2014).

34. Thatje, S., Hillenbrand, C. -D., Mackensen, A. \& Larter, R. Life hung by a thread: endurance of Antarctic fauna in glacial periods. Ecology 89, 682-692 (2008).

35. Rogers, A. D. in Antarctic Ecosystems. An Extreme Environment in a Changing World (eds Rogers, A. D., Johnston, N. M., Murphy, E. J., \& Clarke, A.) 417-467 (WileyBlackwell, Oxford, 2012).

36. Allcock, A. L. \& Strugnell, J. M. Southern Ocean diversity: new paradigms from molecular ecology. Trends Ecol. Evol. 27, 520-528 (2012).

37. Barnes, D. K. A. \& Hillenbrand, C. -D. Faunal evidence for a late Quaternary transAntarctic seaway. Global Change Biol. 16, 3297-3303 (2010).

This ecological study showed striking similarities in bryozoan assemblages in the Weddell and Ross Seas, supporting the hypothesis that partial collapse of the West 


\section{Antarctic Ice Sheet during Pleistocene interglacials created a trans-Antarctic}

seaway.

38. Pierrat, B., Saucède, T., Brayard, A., David, B. \& Crame, A. Comparative biogeography of echinoids, bivalves and gastropods from the Southern Ocean. $J$. Biogeogr. 40, 1374-1385 (2013).

39. Peat, H. J., Clarke, A. \& Convey, P. Diversity and biogeography of the Antarctic flora. J. Biogeogr. 34, 132-146 (2006).

40. Stevens, M. I. \& Hogg, I. D. in Trends in Antarctic Terrestrial and Limnetic Ecosystems (eds Bergstrom, D. M., Convey, P., \& Huiskes, A. H. L.) 177-192 (Springer, Dordrecht, 2006).

41. Velasco-Castrillón, A., Gibson, J. A. E. \& Stevens, M. I. A review of current Antarctic limno-terrestrial microfauna. Polar Biol. 37, 1517-1531 (2014).

42. Velasco-Castrillón, A. \& Stevens, M. I. Morphological and molecular diversity at a regional scale: a step closer to understanding Antarctic nematode biogeography. Soil Biol. Biochem. 70, 272-284 (2014).

43. Torricelli, G. et al. High divergence across the whole mitochondrial genome in the "pan-Antarctic" springtail Friesea grisea: evidence for cryptic species? Gene 449, 3040 (2010).

44. Terauds, A. et al. Conservation biogeography of the Antarctic. Divers. Distrib. 18, 726$741(2012)$.

45. Pisa, S. et al. The cosmopolitan moss Bryum argenteum in Antarctica: recent colonisation or in situ survival? Polar Biol. 37, 1469-1477 (2014).

46. McGaughran, A., Stevens, M. I., Hogg, I. D. \& Carapelli, A. Extreme glacial legacies: a synthesis of the Antarctic springtail phylogeographic record. Insects 2, 62-82 (2011). 
47. Vyverman, W. et al. Evidence for widespread endemism among Antarctic microorganisms. Polar Sci. 4, 103-113 (2010).

48. Zablocki, O. et al. High-level diversity of tailed phages, eukaryote-associated viruses, and virophage-like elements in the metaviromes of Antarctic soils. Appl. Env. Microbiol. 80, 6888-6897 (2014).

49. Yergeau, E. et al. Size and structure of bacterial, fungal and nematode communities along an Antarctic environmental gradient. FEMS Microbiol. Ecol. 59, 436-451 (2007).

50. Cary, S. C., McDonald, I. R., Barrett, J. E. \& Cowan, D. A. On the rocks: the microbiology of Antarctic Dry Valley soils. Nature Rev. Microbiol. 8, 129-138 (2010).

51. Fierer, N. et al. Cross-biome metagenomic analyses of soil microbial communities and their functional attributes. Proc. Natl. Acad. Sci. U.S.A. 109, 21390-21395 (2012).

52. Lee, C. K., Barbier, B. A., Bottos, E. M., McDonald, I. R. \& Cary, S. C. The intervalley soil comparative survey: the ecology of Dry Valley edaphic microbial communities. ISME J. 6, 1046-1057 (2012).

53. Chan, Y., Van Nostrand, J. D., Zhou, J., Pointing, S. B. \& Farrell, R. L. Functional ecology of an Antarctic Dry Valley. Proc. Natl. Acad. Sci. U.S.A. 110, 8990-8995 (2013).

This study showed, using a metagenomic approach, significant plasticity in autotrophic, diazotrophic and heterotrophic strategies which support microbial communities in the Antarctic Dry Valleys.

54. Laybourn-Parry, J. \& Pearce, D. A. The biodiversity and ecology of Antarctic lakes: models for evolution. Phil. Trans. R. Soc. B 362, 2273-2289 (2007).

55. Anesio, A. M. \& Bellas, C. M. Are low temperature habitats hot spots of microbial evolution driven by viruses? Trends Microbiol. 19, 52-57 (2011). 
56. Varin, T., Lovejoy, C., Jungblut, A. D., Vincent, W. F. \& Corbeil, J. Metagenomic analysis of stress genes in microbial mat communities from Antarctica and the High Arctic. Appl. Env. Microbiol. 78, 549-559 (2012).

57. Christner, B. C. et al. A microbial ecosystem beneath the West Antarctic ice sheet. Nature 512, 310-313 (2014).

This study showed that subglacial Lake Whillans, which lies below $800 \mathrm{~m}$ of ice, has a diverse, chemosynthetically driven assemblage of Bacteria and Archaea, thus verifying the existence of deep, subglacial life.

58. Pennycuick, C. J. in Comparative Physiology: Life in Water and on Land Vol. 9 (eds Dejours, P., Bolis, L., Taylor, C. R., \& Weibel, E. R.) 371-386 (Liviana Press, Padova, 1987).

59. Weimerskirch, H., Louzao, M., de Grissac, S. \& Delord, K. Changes in wind pattern alter albatross distribution and life-history traits. Science 335, 211-214 (2012).

60. Green, T. G. A., Sancho, L. G., Pintado, A. \& Schroeter, B. Functional and spatial pressures on terrestrial vegetation in Antarctica forced by global warming. Polar Biol. 34, 1643-1656 (2011).

61. Fraser, C. I., Terauds, A., Smellie, J., Convey, P. \& Chown, S. L. Geothermal activity helps life survive glacial cycles. Proc. Natl. Acad. Sci. U.S.A. 111, 5634-5639 (2014).

62. Hawes, T. C. Antarctica's geological arks of life. J. Biogeogr. 42, 207-208 (2015).

63. Barrett, J. E. et al. Co-variation in soil biodiversity and biogeochemistry in northern and southern Victoria Land, Antarctica. Antarct. Sci. 18, 535-548 (2006).

64. Pointing, S. B. et al. Highly specialized microbial diversity in hyper-arid polar desert. Proc. Natl. Acad. Sci. U.S.A. 106, 19964-19969 (2009).

This study showed that significant microbial diversity exists as four distinct communities, including three lithic ones, in the hyper-arid Antarctic Dry Valleys. 
65. Pearce, D. A. et al. Microorganisms in the atmosphere over Antarctica. FEMS Microbiol. Ecol. 69, 143-157 (2009).

66. Herbold, C. W., Lee, C. K., McDonald, I. R. \& Cary, S. C. Evidence of global-scale aeolian dispersal and endemism in isolated geothermal microbial communities of Antarctica. Nature Comms. 5, 3875 (2014).

67. Gordon, D. A., Priscu, J. \& Giovannoni, S. Origin and phylogeny of microbes living in permanent Antarctic lake ice. Microbial Ecol. 39, 197-202 (2000).

68. Archer, S. D., McDonald, I. R., Herbold, C. W. \& Cary, S. C. Characterisation of bacterioplankton communities in the meltwater ponds of Bratina Island, Victoria Land, Antarctica. FEMS Microbiol. Ecol. 89, 451-464 (2014).

69. Bowman, J. P., McCammon, S. A., Rea, S. M. \& McMeekin, T. A. The microbial composition of three limnologically disparate hypersaline Antarctic lakes. FEMS Microbiol. Lett. 183, 81-88 (2000).

70. Villaescusa, J. A. et al. A close link between bacterial community composition and environmental heterogeneity in maritime Antarctic lakes. Internat. Microbiol. 13, 67-77 (2010).

71. Lauro, F. M. et al. An integrative study of a meromictic lake ecosystem in Antarctica. ISME J. 5, 879-895 (2011).

72. Bielewicz, S. et al. Protist diversity in a permanently ice-covered Antarctic lake during the polar night transition. ISME J. 5, 1559-1564 (2011).

73. Lefebvre, V., Donnadieu, Y., Sepulchre, P., Swingedouw, D. \& Zhang, Z.-S. Deciphering the role of southern gateways and carbon dioxide on the onset of the Antarctic Circumpolar Current. Paleoceanography 27, PA4201 (2012). 
74. Leese, F., Agrawal, S. \& Held, C. Long-distance island hopping without dispersal stages: transportation across major zoogeographic barriers in a Southern Ocean isopod. Naturwissenschaften 97, 583-594 (2010).

75. Fraser, C. I., Nikula, R., Ruzzante, D. E. \& Waters, J. M. Poleward bound: biological impacts of Southern Hemisphere glaciation. Trends Ecol. Evol. 27, 462-471 (2012).

76. Thornhill, D. J., Mahon, A. R., Norenburg, J. L. \& Halanych, K. M. Open-ocean barriers to dispersal: a test case with the Antarctic Polar Front and the ribbon worm Parborlasia corrugatus (Nemertea: Lineidae). Mol. Ecol. 17, 5104-5117 (2008).

77. Poulin, E., González-Wevar, C., Díaz, A., Gérard, K. \& Hüne, M. Divergence between Antarctic and South American marine invertebrates: what molecular biology tells us about Scotia Arc geodynamics and the intensification of the Antarctic Circumpolar Current. Global Planet. Change 123, 392-399 (2014).

78. Page, T. J. \& Linse, K. More evidence of speciation and dispersal across the Antarctic Polar Front through molecular systematics of Southern Ocean Limatula (Bivalvia: Limidae). Polar Biol. 25, 818-826 (2002).

79. Wilson, N. G., Schrodl, M. \& Halanych, K. M. Ocean barriers and glaciation: evidence for explosive radiation of mitochondrial lineages in the Antarctic sea slug Doris kerguelenensis (Mollusca, Nudibranchia). Mol. Ecol. 18, 965-984 (2009).

80. Díaz, A., Féral, J. P., David, B., Saucède, T. \& Poulin, E. Evolutionary pathways among shallow and deep-sea echinoids of the genus Sterechinus in the Southern Ocean. Deep Sea Res. II 58, 205-211 (2011).

81. O’Hara, T. D., Smith, P. J., Mills, V. S., Smirnov, I. \& Steinke, D. Biogeographical and phylogeographical relationships of the bathyal ophiuroid fauna of the Macquarie Ridge, Southern Ocean. Polar Biol. 36, 321-333 (2012). 
82. Hunter, R. L. \& Halanych, K. M. Evaluating connectivity in the brooding brittle star Astrotoma agassizii across the Drake Passage in the Southern Ocean. J. Heredity 99, 137-148 (2008).

83. Barnes, D. K. A., Hodgson, D. A., Convey, P., Allen, C. S. \& Clarke, A. Incursion and excursion of Antarctic biota: past, present and future. Global Ecol. Biogeogr. 15, 121$142(2006)$.

84. Huiskes, A. H. L. et al. Aliens in Antarctica: assessing transfer of plant propagules by human visitors to reduce invasion risk. Biol. Conserv. 171, 278-284 (2014).

85. Molina-Montenegro, M. A. et al. Assessing the importance of human activities for the establishment of the invasive Poa annua in Antarctica. Polar Res. 33, 21425 (2014).

86. Volonterio, O., de León, R. P., Convey. P. \& Krzemińska, E. First record of Trichoceridae (Diptera) in the maritime Antarctic. Polar Biol. 36, 1125-1131 (2013).

87. Lewis, P. N., Riddle, M. \& Hewitt, C. L. Management of exogenous threats to Antarctica and the sub-Antarctic Islands: balancing the risks from TBT and nonindigenous marine organisms. Mar. Poll. Bull. 49, 999-1005 (2004).

This study showed that a diverse fouling community can be transported to Antarctica on the hulls of research vessels, though sea-ice may reduce the numbers of organisms being transported.

88. Aronson, R. B., Frederich, M., Price, R. \& Thatje, S. Prospects for the return of shellcrushing crabs to Antarctica. J. Biogeogr. 42, 1-7 (2015).

89. Griffiths, H. J., Whittle, R. J., Roberts, S. J., Belchier, M. \& Linse, K. Antarctic crabs: invasion or endurance? PLoS One 8, e66981 (2013).

90. Berkman, P. A., Lang, M. A., Walton, D. W. H. \& Young, O. R. (eds.) Science Diplomacy. Antarctica, Science, and the Governance of International Spaces. (Smithsonian Institution, Washington D.C., 2011). 
91. Convention on Biological Diversity. National Biodiversity Strategy and Action Plans. http://www.cbd.int/nbsap/ (2015).

92. Shaw, J. D., Terauds, A., Riddle, M. J., Possingham, H. P. \& Chown, S. L. Antarctica's protected areas are inadequate, unrepresentative, and at risk. PLoS Biol. 12, e1001888 (2014).

93. Hughes, K. A. \& Convey, P. The protection of Antarctic terrestrial ecosystems from inter- and intra-continental transfer of non-indigenous species by human activities: a review of current systems and practices. Global Environ. Change 20, 96-112 (2010).

94. Braun, C. et al. in Antarctic Futures. Human Engagement with the Antarctic Environment (eds Tin, T., Liggett, D., Maher, P. T., \& Lamers, M.) 169-191 (Springer, Dordrecht, 2014).

95. CEP (Committee for Environmental Protection) Non-native species manual. Buenos Aires, http://www.ats.aq/e/ep_fafl_nns.htm (2011).

96. Nielsen, U. N. \& Wall, D. H. The future of soil invertebrate communities in polar regions: different climate change responses in the Arctic and Antarctic? Ecol. Lett. 16, 409-419 (2013).

97. Smith, W. O., Jr., Ainley, D. G., Arrigo, K. R. \& Dinniman, M. S. The oceanography and ecology of the Ross Sea. Annu. Rev. Mar. Sci. 6, 469-487 (2014).

98. Ainley, D. G. et al. Decadal trends in abundance, size and condition of Antarctic toothfish in McMurdo Sound, Antarctica, 1972-2011. Fish Fisher. 14, 343-363 (2013).

99. Brady, A. -M. (ed.) The Emerging Politics of Antarctica (Routledge, Abingdon, 2013).

100. Puig-Marcó, R. Access and benefit sharing of Antarctica's biological material. Mar. Genom. 17, 73-78 (2014).

101. Wan, E. et al. Green technologies for room temperature nucleic acid storage. Curr. Iss. Mol. Biol. 12, 135-142 (2010). 
102. Fretwell, P. T. et al. An emperor penguin population estimate: the first global, synoptic survey of a species from space. PLoS One 7, e33751 (2012).

This study showed that a synoptic survey of the entire population of an important Antarctic species, the Emperor Penguin, can be undertaken for a single year by satellite remote sensing, with the numbers of breeding pairs estimated increasing over previous counts by $>50000$.

103. Shin, J. -I., Kim, H. -C., Kim, S. -I. \& Hong, S. G. Vegetation abundance on the Barton Peninsula, Antarctica: estimation from high-resolution satellite images. Polar Biol. 37, $1579-1588$ (2014).

104. Van Dorst, J. et al. Community fingerprinting in a sequencing world. FEMS Microbiol. Ecol. 89, 316-330 (2014).

105. Lynch, H. J., Naveen, R., Trathan, P. N. \& Fagan, W. J. Spatially integrated assessment reveals widespread changes in penguin populations on the Antarctic Peninsula. Ecology 93, 1367-1377 (2012).

106. Peck, L. S. \& Clark, M. S. in Adaptation and Evolution in Marine Environments, Volume 1 (eds di Prisco, G. \& Verde, C.) 157-182 (Springer, Berlin, 2012).

107. Bednaršek, N. et al. Extensive dissolution of live pteropods in the Southern Ocean. Nature Geosci. 5, 881-885 (2012).

108. Kawaguchi, S. et al. Risk maps for Antarctic krill under projected Southern Ocean acidification. Nature Climate Change 3, 843-847 (2013).

109. Ansorge, I. J. \& Lutjeharms, J. R. E. Eddies originating at the South-West Indian Ridge. J. Mar. Syst. 39, 1-18 (2003).

110. Fretwell, P. et al. Bedmap2: improved ice bed, surface and thickness datasets for Antarctica. Cryosphere 7, 375-393 (2013). 
Acknowledgments This work was supported by Australian Research Council grants DP140102815 to S.L.C. and DP150103017 to M.A.M., an Australian Research Council Discovery Early Career Fellowship DE140101715 to C.I.F., grants from the New Zealand Antarctic Research Institute, New Zealand Marsden Fund and the U.S. National Science Foundation to S.C.C., and emeritus support from the British Antarctic Survey to A.C. We thank D.J. Marshall, C. Lee and H.W. Morgan for comments that improved the work.

Author Contributions S.L.C., S.C.C. and M.A.M. conceived the work; C.I.F conceptualized and drew the figures; all authors contributed equally to the planning and writing of the manuscript.

Author Information Reprints and permissions information is available at www.nature.com/reprints. The authors declare no competing financial interests. Correspondence should be addressed to S.L.C. (steven.chown@monash.edu). 


\section{Box 1 | Impacts of anthropogenic environmental change on Southern Ocean systems}

Conceptualized impacts of local (resource exploitation, invasive species) and global (climate change, including increasing $\mathrm{CO}_{2}$ concentrations which result in ocean acidification) environmental change drivers on Southern Ocean systems. Direct impacts are shown by light blue arrows and indirect impacts by light red ones. The large red and green arrows indicate declines or increases in populations, respectively. Human impacts commenced with the exploitation of whales and seals, which has now largely ceased. The main focus of exploitation is now fish ${ }^{10,98}$ and krill, which not only has direct impacts on their populations, but can also affect other species which either depend on these organisms as a resource ${ }^{105}$, or which are caught incidentally (such as some seabirds). Fishing outside the region also influences seabird populations as a consequence of incidental mortality. Climate change is having complex impacts through changes in sea ice distribution and temperature ${ }^{97,105}$. In the future, limited physiological tolerances and their capacity for change may have considerable effects both on vertebrates and invertebrates ${ }^{11,106}$. Ocean acidification is already affecting calcified organisms ${ }^{107}$, and may influence krill via impacts on eggs ${ }^{108}$. Although records of marine invasive species are uncommon, introductions, such as of crabs, may pose considerable threats to local communities ${ }^{88}$. 
Box 2 | The relevance to the Antarctic of the 20 Aichi Targets under the Strategic Plan for Biodiversity 2011-2020 of the Conference of Parties to the Convention on Biological Diversity. Highlighted targets are most relevant to the region

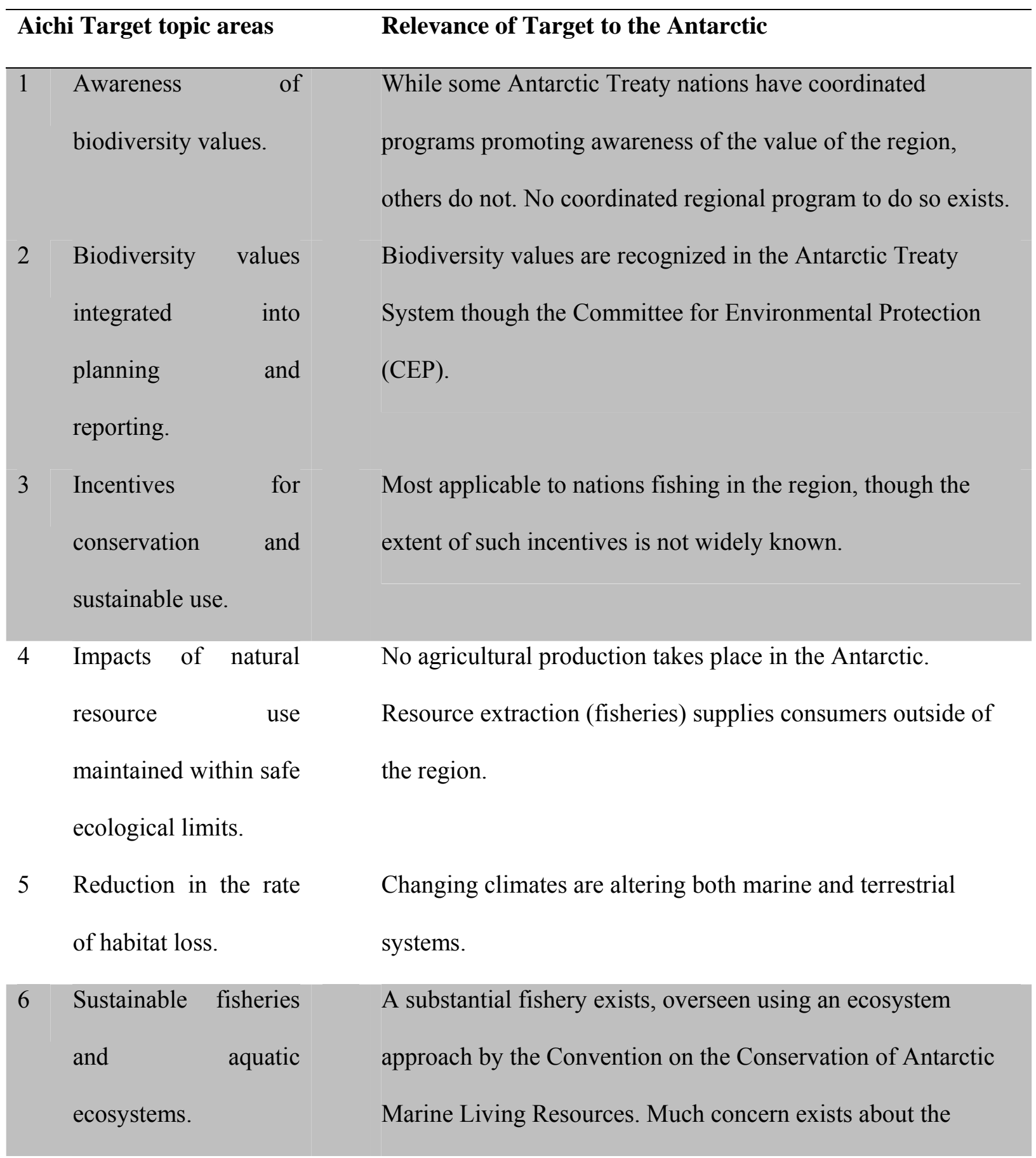




\begin{tabular}{|c|c|c|}
\hline & & sustainability of the fishery ${ }^{10,98}$. \\
\hline 7 & $\begin{array}{l}\text { Sustainable } \\
\text { production systems. }\end{array}$ & No area is currently under production. \\
\hline 8 & Pollution reduction. & $\begin{array}{l}\text { Point source pollution is limited with significant effort to } \\
\text { reduce it. }\end{array}$ \\
\hline 9 & $\begin{array}{l}\text { Prevention and } \\
\text { management of } \\
\text { biological invasions. }\end{array}$ & $\begin{array}{l}\text { Non-indigenous species are a major concern for the region, and } \\
\text { are a priority for the CEP. Activity to control species and } \\
\text { pathways is inconsistent and uncoordinated. }\end{array}$ \\
\hline 10 & $\begin{array}{l}\text { Pressures on marine } \\
\text { ecosystems impacted } \\
\text { by climate change. }\end{array}$ & $\begin{array}{l}\text { Ocean acidification is a substantial threat to Southern Ocean } \\
\text { ecosystems } \\
97,107,108\end{array}$ \\
\hline 11 & $\begin{array}{l}\text { Targets for protected } \\
\text { areas. }\end{array}$ & $\begin{array}{l}\text { Only } 1.5 \% \text { of terrestrial biodiversity area is formally protected. } \\
\text { Management is inadequate }{ }^{93} \text {. The designation of Marine } \\
\text { Protected areas is controversial. }\end{array}$ \\
\hline 12 & $\begin{array}{l}\text { Improvement in } \\
\text { species conservation } \\
\text { status. }\end{array}$ & $\begin{array}{l}\text { Knowledge of the conservation status of taxa is poor, other than } \\
\text { for most birds and mammals. }\end{array}$ \\
\hline 13 & $\begin{array}{l}\text { Safeguarding genetic } \\
\text { diversity of valuable } \\
\text { species. }\end{array}$ & $\begin{array}{l}\text { Largely not relevant, although bioprospecting is growing }{ }^{100} \text {. } \\
\text { Southern Ocean ecosystems are important for whales, which } \\
\text { have cultural value. }\end{array}$ \\
\hline 14 & $\begin{array}{l}\text { Restoration of } \\
\text { ecosystem services. }\end{array}$ & $\begin{array}{l}\text { Antarctic ecosystems provide several services essential to } \\
\text { planetary stability, including maintenance of land ice to prevent } \\
\text { sea level rise, and climate regulation. }\end{array}$ \\
\hline 15 & $\begin{array}{l}\text { Contribution to } \\
\text { climate change }\end{array}$ & $\begin{array}{l}\text { Not relevant to terrestrial systems. Its likely relevance is } \\
\text { through marine system contributions to } \mathrm{CO}_{2} \text { sequestration. }\end{array}$ \\
\hline
\end{tabular}


mitigation.

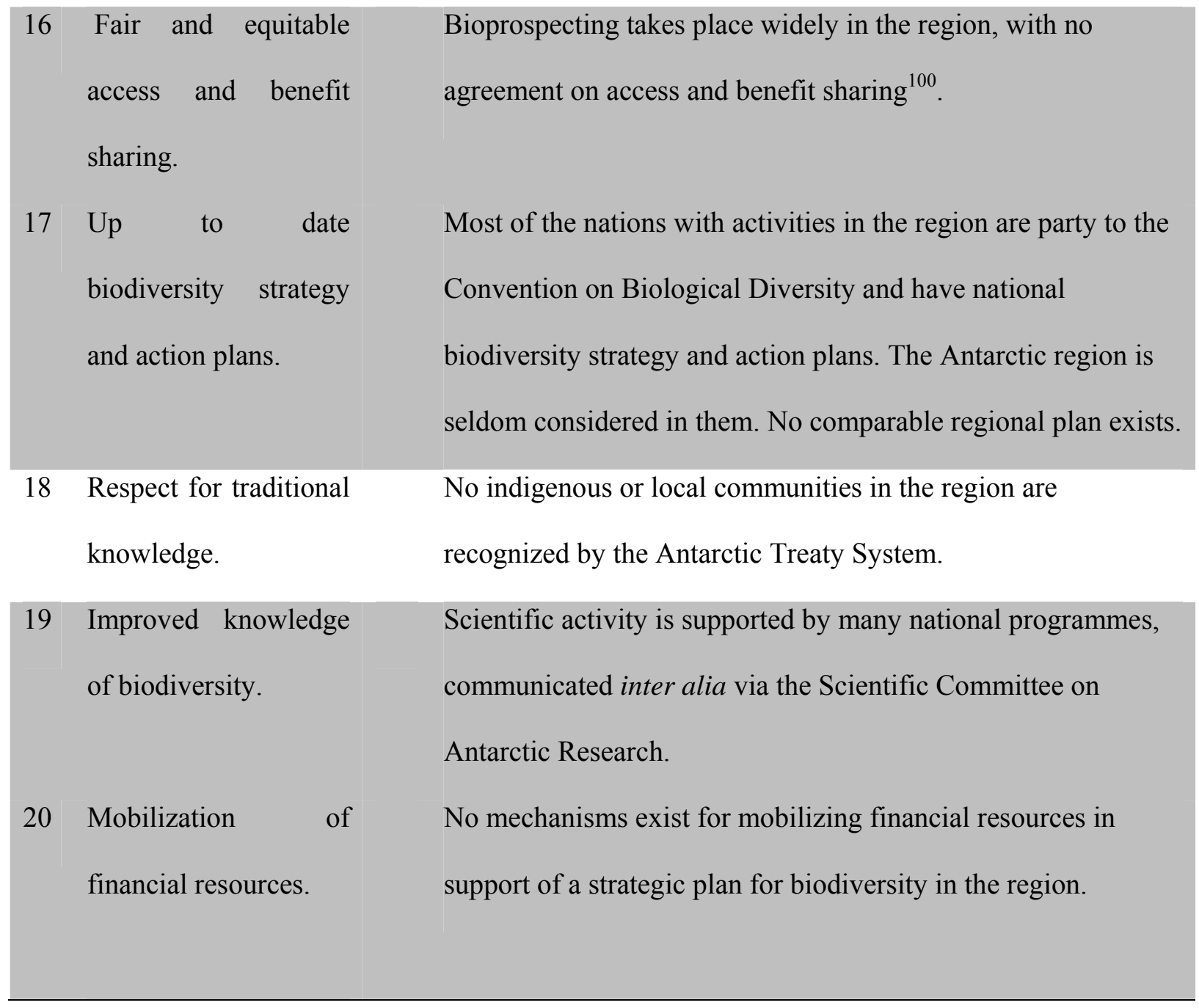




\section{Figure 1 | The Antarctic region is neither as isolated nor as depauperate in biodiversity}

as once thought. Oceanic fronts can be permeable, with meso-scale eddies transporting pockets of water and associated organisms across them (inset figure lower left modified from ref. 109). Dispersal of marine species around Antarctica has been facilitated by the Antarctic Circumpolar Current (ACC) and Antarctic Coastal Current (ACoC), as well as by transAntarctic seaways during some interglacials ${ }^{37}$. Glacial cycles have driven diversification, with some species surviving within the Antarctic region during glacial periods - e.g. in terrestrial refugia such as geothermal $\operatorname{areas}^{61}$ or marine shelf refugia ${ }^{36}$ - and undergoing allopatric divergence. Species flock radiations have been inferred for some groups, such as Antarctic notothenioid fish which have diversified during periods of climate change (tree derived from ref. 32). The mean positions of the major oceanic fronts are shown: Southern Antarctic Circumpolar Current Front (SACCF), Antarctic Polar Front (APF), Subantarctic Front (SAF) and the Subtropical Front (STF). Locations of possible terrestrial geothermal refugia (volcanoes and heated rocks) are indicated by yellow dots ${ }^{61}$. Antarctic bedrock $(>0$ m) is roughly indicated in pale brown (derived from ref. 110), and the Antarctic continental shelf in blue (not shown for other continents). The diversity and position of the 15 distinct Antarctic Conservation Biogeographic regions ${ }^{44}$ are indicated in the central panel on the right. 


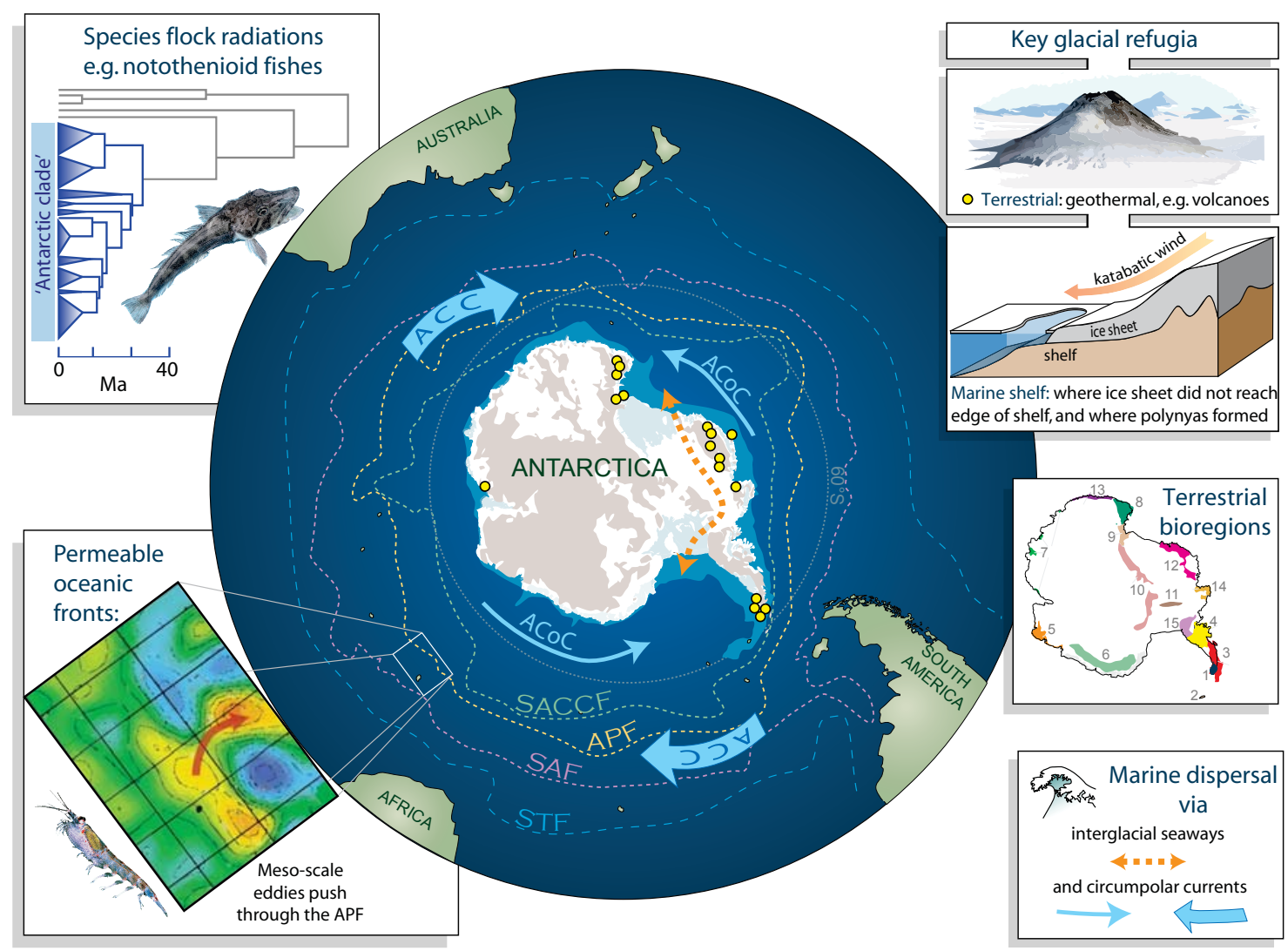




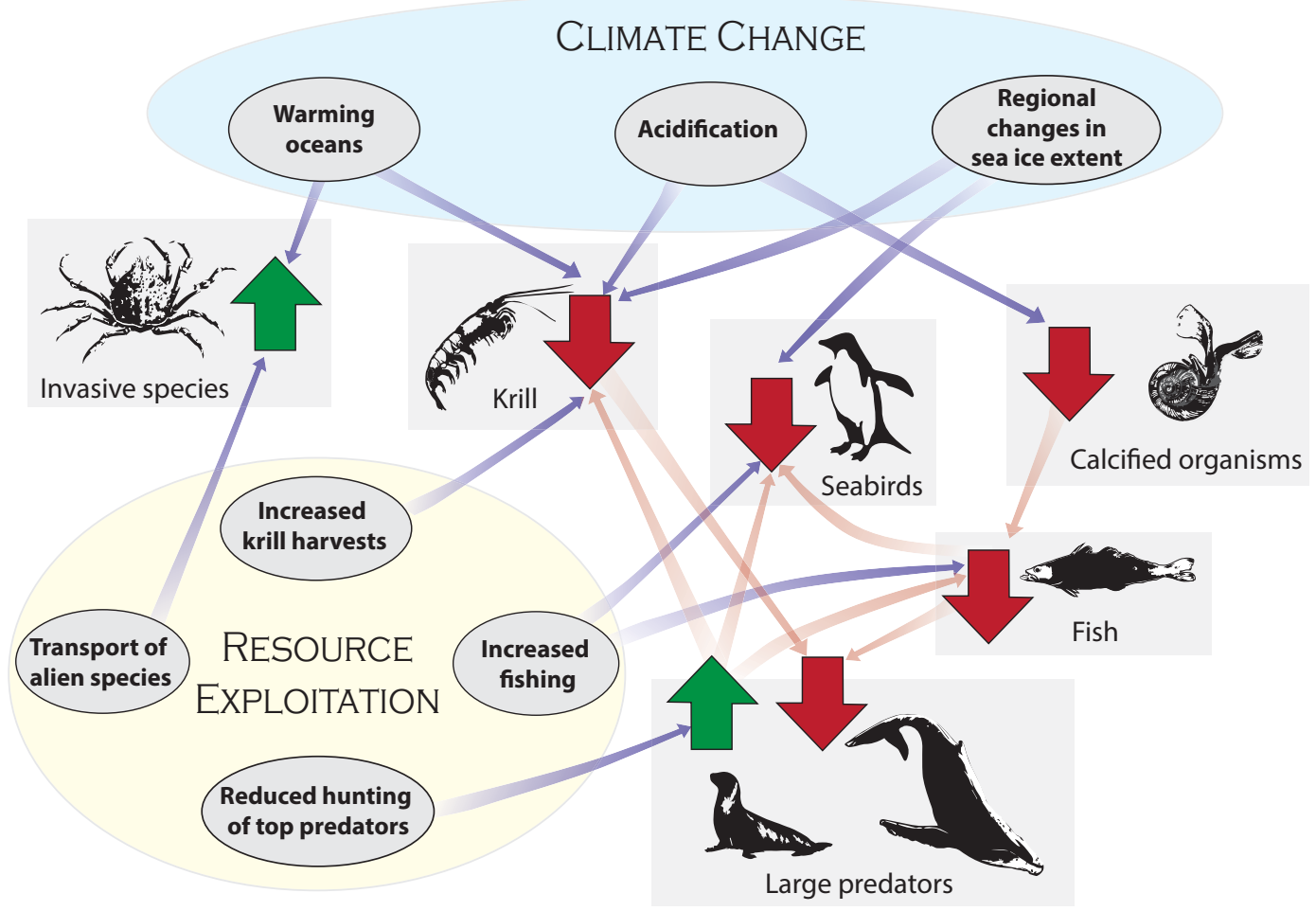

